\title{
Ammonia Volatilization from Frequently Applied Fertilizers for the Low-Country Tea Growing Soils of Sri Lanka
}

\author{
L.R.M.C. Liyanage $^{1 *}$, A.N. Jayakody ${ }^{2}$ and G.P. Gunaratne ${ }^{1}$ \\ Postgraduate Institute of Agriculture \\ University of Peradeniya \\ Sri Lanka
}

\begin{abstract}
Ammonia volatilization is one of the major nitrogen loosing pathways in agricultural fields. Particularly, Low-country tea growing areas of Sri Lanka having warm humid climate, often records low or poor responses to current fertilizer recommendations. Therefore, a glasshouse experiment was conducted to determine the gravity of ammonia volatilized from four major tea growing Soil Series of the Low-country wet zone. Air tightened closed chambers with soils containing acid traps were used to quantify ammonia volatilized from applied fertilizers. The experiment was conducted for 100 days while monitoring temperature and relative humidity in the glasshouse which were comparable with prevailing conditions in the low-country wet zone. Volatilized ammonia was quantified daily at the beginning and later with elapsed time. Curves defining the release of ammonia with time and the change of $\mathrm{pH}$ with time were plotted from the results.
\end{abstract}

Significant differences were observed in soil pH changes among treatments. Sulphate of ammonia based T1130 mixture recorded the least change in soil $\mathrm{pH}$ while urea based VPLC 880 showed the highest variation. During the experimental period, highest $\mathrm{pH}$ was recorded at the fourth day after treatment application which confirms the peak hydrolysis of urea. No significant differences were recorded in soil pH changes with soil series. Ammonia volatilization was lowest in $T 1130$ treatment and it behaved similar to the control treatment without fertilization. Ammonia losses were highest in VPLC 880 fertilizer amounting to 29\%. Other urea based mixtures also showed considerably higher losses as U 709 - 27\%, U834 $27 \%$, UT $752-26 \%$. T 1130 showed minimum losses as $1 \%$ similar to the control. Among soil Series $\mathrm{NH}_{3}$ losses sequenced as Dodangoda $>$ Weddagala $>$ Malaboda $>$ Pallegoda. As these soils show lower $\mathrm{pH}$ buffering ability, split application of urea based fertilizers may effective to minimize said $\mathrm{NH}_{3}$ losses.

Keywords: Ammonia volatilization, fertilizers, $p H$, soil series, tea

1 Soils and Plant Nutrition Division, Tea Research Institute of Sri Lanka, Talawakelle, Sri Lanka;

Department of Soil Science, Faculty of Agriculture, University of Peradeniya, Peradeniya, Sri Lanka

* Corresponding author: 1rmcliyanage@ asia.com 


\section{INTRODUCTION}

Tea (Camellia sinensis) is one of the highest nitrogen demanding plantation crops of which the young tender leaves are periodically removed as the harvest. At present, In Sri Lanka, Nitrogen is provided based on the potential yields ranging from $90-400 \mathrm{~kg} / \mathrm{ha} /$ year (Anon, 2000). In general, $270 \mathrm{~kg}$ of $\mathrm{N} / \mathrm{ha} / \mathrm{year}$ is recommended for harvesting of $2000-2500$ $\mathrm{kg} / \mathrm{ha} /$ year made tea. Nitrogen content in mature leaves amounts to $3-5 \%$ depending on the clone and the maturity stage. Most of mature tea fertilizer mixtures contain around $30 \% \mathrm{~N}$, while $\mathrm{K}_{2} \mathrm{O}$ and $\mathrm{P}_{2} \mathrm{O}_{5}$ are around $13 \%$ and $4 \%$ respectively (Anon, 2000 ${ }^{\mathrm{a}}, 2010$ ). Tea is fertilized with 3 or 4 applications per year depending on the climatic conditions prevailing. Currently, urea is the sole nitrogen source blended to all mature tea mixtures in Sri Lanka, especially considering the cost and the easiness to handle.

Ammonia volatilization is one of the major pathways of nitrogen losses from applied manure/fertilizer as well as from native soil (Prasertsak et al., 2001). Early studies in the $20^{\text {th }}$ century itself suggested the gravity of ammonia volatilization losses as worthy to be quantified (Gordon et al, 1988). Salter and Schollenberger (1938) indicated, that up to 50\% of the total nitrogen in manure at the time of spreading could be lost through volatilization of ammonia under favourable conditions. Further, Adriano et al. (1971) and Hoff et al. (1981) estimated that the volatilization losses may range from $20-80 \%$ of applied $\mathrm{N}$ in manure occurring even between 3-5 days after manure applications. Major factors influencing ammonia volatilization from added fertilizers are soil $\mathrm{pH}$, soil moisture, water evaporation, wind velocity, cation exchange capacity (CEC), temperature, humidity, gas exchange, textural class and type of fertilizer added etc. (Fenn and Kissel, 1976; Freney et al., 1985; Hargrove, 1988; Byrnes, 2000). In addition, soil pH buffering capacity exerts a greater influence in retaining $\mathrm{NH}_{3}-\mathrm{N}$ in soils (Ferguson et al., 1984). Surface roughness helps to reduce ammonia losses acting as a wind barrier thus reducing physical transport of $\mathrm{NH}_{3}$ from the soil to the atmosphere. Microbial activities and urease enzyme activities also influence $\mathrm{NH}_{3}$ losses (Bavananthan and Fernando, 1970).

The volatilization process involves, at first, urea hydrolysis through urease. Urease is an extra-cellular enzyme produced by several soil microorganisms or plant residues. During hydrolysis two $\mathrm{H}^{+}$ions are consumed by one urea molecule and thus $\mathrm{pH}$ will be increased up to 7 or even to 9 in most soils. Along with the rise in $\mathrm{pH}$, the proportion of nitrogen in the form of $\mathrm{NH}_{3}$ gas becomes larger and volatilization of $\mathrm{NH}_{3}$ could occur. Quantification of ammonia volatilization is a tedious task as it is governed by a multitude of factors (Gordon et al., 1988). The prediction of actual $\mathrm{NH}_{3}$ volatilization losses under a given set of soil and environmental conditions could seldom be achieved, due to the complexity of interactions taking place (Ping et al., 2000).

Despite numerous studies conducted for $\mathrm{NH}_{3}$ volatilization, only a few studies have been performed in relation to tea cultivation in Sri Lanka. The Tea Research Institute of Sri Lanka (TRISL) has conducted lengthily studies to compare and contrast urea and sulphate of ammonia (SA) for fertilization of tea and arrived at the conclusion to use urea in all mature tea fertilizer mixtures (Bavananthan and Fernando, 1970; Sivasubramanium, 1980 and Wickramasinghe et al., 1985, 1986). However, most of these studies were confined to upcountry tea growing soils (elevation $>900 \mathrm{~m}$ ) having higher CEC and higher organic matter contents leading to higher $\mathrm{pH}$ buffering capacities. In contrast, the low country tea growing 
soils (elevation $0-300 \mathrm{~m}$ ) have been found to be comparatively lower in $\mathrm{pH}$ buffering capacities (Liyanage et al., 2012).

Recently, many tea growers of the Low - Country have lodged a view to the TRISL claiming that an ammonia smell has been experienced by them subsequent to each and every fertilizer application (personal communication). Besides, their complain has been tagged to a shortterm effect of applied fertilizer on expected yields forcing them to practice a higher number of applications than recommended, which has to be considered as unaffordable and uneconomical for them. Some were of the view that the straight fertilizers and mixtures provided to them are of lower quality.

Hence, to ascertain the scientific truth of what has been observed and experienced by the growers, the major objective of the present study was to quantify the ammonia losses from soils under current use of tea fertilizer mixtures in the Low-Country also giving due consideration to some related aspects such as $\mathrm{pH}$ and $\mathrm{pH}$ buffering ability, source of $\mathrm{N}$ and $\mathrm{N}$ : $\mathrm{K}$ ratios in mixtures.

\section{MATERIALS AND METHODS}

A glass-house experiment was conducted to estimate the ammonia volatilization losses from currently used mature tea fertilizer mixtures in the Low-Country tea growing areas with using four major Soil Series exploited for tea. The experiment was conducted in a glasshouse at the TRISL Mid-Country Regional Centre subsequent to the verification of the possibility to manipulate low-country conditions. Prior recording of temperature and relative humidity inside the glasshouse were made and adjusted to be comparable to the prevailing low-country atmospheric temperature and relative humidity conditions.

Soils from four major tea growing Soil Series from the Low-Country namely Malaboda, Weddagala, Dodangoda and Pallegoda from Balangoda, Deniyaya, Handapangoda and Wanduramba respectively were selected for the study to represent the Low country region (Figure 1). Samples were drawn from a depth of $0-15 \mathrm{~cm}$ representing $A_{p}$, A and part of B horizons and transported to the glass-house. 


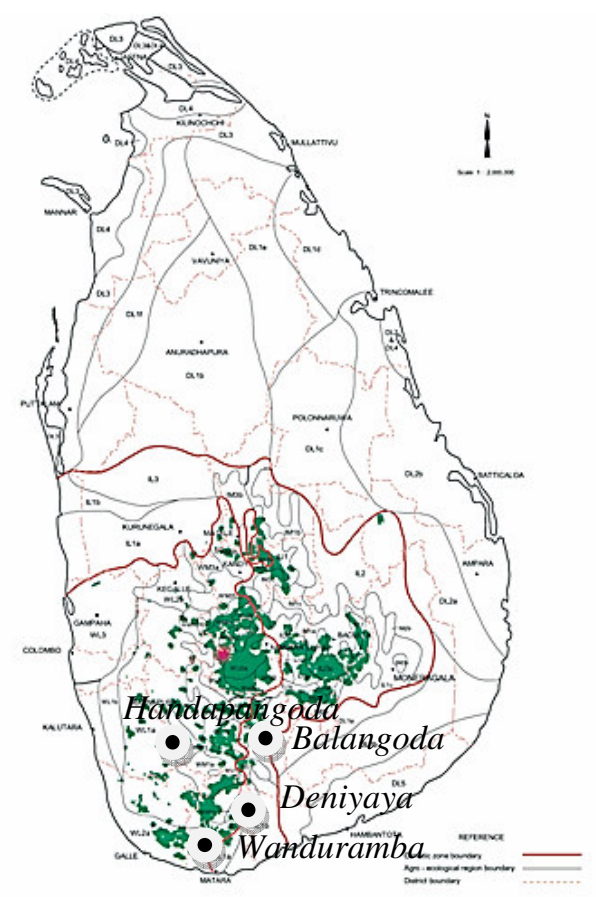

Fig: 1. Soil sampling sites of the low country tea growing regions

Seventy two soil samples were taken in total by drawing 18 soil samples from each site. Fresh soils were sieved through $5 \mathrm{~mm}$ mesh and filled into plastic pots having $20 \mathrm{~cm}$ inner diameter. Three replicates were used for each treatment per site and $4 \mathrm{~kg}$ of soil were filled to each pot and compacted to their bulk densities of each and every location. Each pot was weighed and moistened to $60 \%$ of field capacity. These pots were arranged based on Soil Series in line with a RCBD design on metal racks in the glasshouse where temperature and $\mathrm{RH}$ changes were monitored throughout the experiment using automatic recorders.

Six treatments including a control were imposed by broadcasting fertilizer on the surface of the soil. Table 1 shows the composition of treatment details along with fertilizer mixtures used in this study. For the treatments, amounts of nutrients were calculated based on the requirements for mature tea as usually adopted in the low country.

Table 1. Amounts of nutrients added to different treatments

\begin{tabular}{lccccc}
\hline \multicolumn{1}{c}{ Treatment } & $\begin{array}{c}\text { Urea; } \boldsymbol{N} \\
(\mathbf{g})\end{array}$ & $\begin{array}{c}\text { ERP; } \boldsymbol{P} \\
(\mathbf{g})\end{array}$ & MOP; $\boldsymbol{K}(\mathbf{g})$ & $\begin{array}{c}\text { Kieserite; } \boldsymbol{M g} \\
(\mathbf{g})\end{array}$ & $\mathbf{S A} \boldsymbol{N}(\mathbf{g})$ \\
\hline T1-U/834 & $8.70 ; 4.00$ & $2.04 ; 0.26$ & $3.33 ; 1.66$ & $2.48 ; 0.36$ & - \\
T2-T/1130 & - & $2.36 ; 0.30$ & $3.33 ; 1.66$ & - & $19.42 ; 4.00$ \\
T3-U/709 & $8.70 ; 4.00$ & $2.04 ; 0.26$ & $3.33 ; 1.66$ & - & - \\
T4-UT/752 & $7.92 ; 3.63$ & $2.06 ; 0.26$ & $3.36 ; 1.67$ & - & $1.70 ; 0.35$ \\
T5-VPLC/880 & $8.70 ; 4.00$ & $1.26 ; 0.16$ & $1.67 ; 0.83$ & - & - \\
T6-Control & 0 & 0 & 0 & 0 & 0 \\
\hline
\end{tabular}


Ammonia gas traps were prepared with standardized $0.5 \mathrm{~N}$ Sulfuric acid and $20 \mathrm{ml}$ of it was used per pot as described by Fenn and Kissel (1973) and Tennakoon et al. (2003). Two plastic boats containing $10 \mathrm{ml}$ of acid were placed on the surface of the each pot and, then one drop of methyl red indicator was added to each boat. The surface of the pot was covered tightly with a piece of transparent polyethylene as shown in the Figure 2 leaving a $3 \mathrm{~cm}$ high air space.

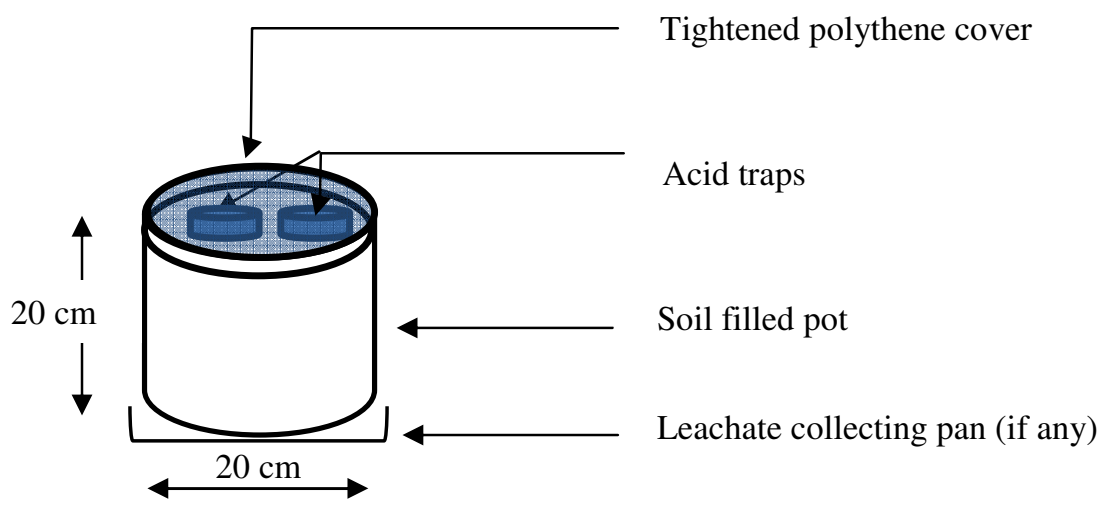

Fig. 2. Schematic diagram of an experimental pot

Acid traps were collected daily during first three days and then in every other day for a week. Thereafter, those were collected in three days interval for three weeks and then once a week for another month. Thereafter, collection was done in 10 days interval. $10 \mathrm{~g}$ of soils were also collected at each sampling time by using a mini soil auger $(1.5 \mathrm{~cm}$ diameter $)$ to measure the $\mathrm{pH}$. Collected acid traps were titrated against $0.01 \mathrm{~N} \mathrm{NaOH}$ to obtain accurate end point and thereby trapped $\mathrm{NH}_{3}$ were calculated. (Fenn and Kissel, 1973). The experiment lasted for 100 days after treatment application. UT 752 treatment received $10 \mathrm{~g}$ of dolomite at 42 days after treatment application as recommended. Pre soil analysis was carried out by using standard analytical methods to check soil fertility status for all four sites and results are shown in the Table 2.

Besides, some initial ammonia measurements were done in form of a Pre-test to receive some ideas about the whole process in view of performing the study more precisely and appropriately.

Collected data were analyzed with proc. GLM procedure for interpretation (Anon, $2000^{\mathrm{b}}$ ). Repeated measurement analysis revealed that the time factor is significant thus, individual data analysis was carried out. Data were analyzed for all soil series together as well as individually and also in treatment basis. Finally, nitrogen balance of each fertilizer treatment was calculated for integrated all tested soils. 
Table 2. Some physical and chemical properties of selected Soil Series.

\begin{tabular}{|c|c|c|c|c|}
\hline Property & Malaboda & Weddagala & Dodangoda & Pallegoda \\
\hline Texture & Clay loam & $\begin{array}{l}\text { Gravelly } \\
\text { loam }\end{array}$ & $\begin{array}{l}\text { Gravelly sandy } \\
\text { clay loam }\end{array}$ & $\begin{array}{l}\text { Sandy } \\
\text { clay loam }\end{array}$ \\
\hline Bulk Density (surface $\mathrm{g} / \mathrm{cm}^{3}$ ) & 1.53 & 1.58 & 1.62 & 1.48 \\
\hline $\mathrm{pH}$ & 4.46 & 4.74 & 4.84 & 4.59 \\
\hline $\mathrm{CEC}\left(\mathrm{cmol}_{\mathrm{c}} / \mathrm{kg}\right)$ & 8.59 & 13.88 & 5.48 & 6.81 \\
\hline Organic carbon $(\%)$ & 1.24 & 1.46 & 1.64 & 1.87 \\
\hline Available K (ppm) & 170 & 122 & 84 & 131 \\
\hline Available $\mathrm{Mg}(\mathrm{ppm})$ & 57 & 53 & 21 & 77 \\
\hline Available $\mathrm{Ca}(\mathrm{ppm})$ & 88 & 214 & 162 & 182 \\
\hline Available P (ppm) & 28.1 & 36.2 & 28.3 & 11.6 \\
\hline Available $\mathrm{SO}_{4}-\mathrm{S}$ (ppm) & 16.5 & 11.2 & 8.2 & 18.6 \\
\hline $\mathrm{NH}_{4}-\mathrm{N}(\mathrm{ppm})$ & 7.5 & 6.4 & 8.0 & 8.3 \\
\hline $\mathrm{NO}_{3}-\mathrm{N}(\mathrm{ppm})$ & 23.4 & 29.1 & 17.7 & 20.4 \\
\hline
\end{tabular}

\section{RESULTS AND DISCUSSION}

\section{Soil pH changes}

Soil pH has changed drastically with treatments. Except for the SA based T 1130, all the other fertilizer treatments showed a similar behaviour where $\mathrm{pH}$ was raised closer to 9 in all sampling sites within a day or two. T 1130 and the control behaved similarly showing no effect of Sulfate of ammonia in changing the $\mathrm{pH}$ as shown in the Figure 3.

All Soil Series tested separately behaved similarly related to changes of soil $\mathrm{pH}$. However, there were no significant differences among soil series and no interaction between treatments and soil series was observed for soil $\mathrm{pH}$ changes at $\mathrm{P} \leq 0.05$. Even though urea containing fertilizer mixtures showed similar patterns in changing of soil pH, VPLC 880 recorded the highest $\mathrm{pH}$ at the fourth day after treatment application among all soils. Urea hydrolysis may have increased the soil $\mathrm{pH}$ where within four days the hydrolysis has been completed in all soil. Wickramasinghe et al. (1985) also reported such results indicating that under optimum conditions, hydrolysis occurs rapidly and hydrolysis completes within seven days in up country tea soils where temperature is comparatively much lower than that of low country tea soils. Thereafter, $\mathrm{pH}$ started to decrease most probably due to the occurrence of nitrification. Dodangoda Soil Series recorded the highest $\mathrm{pH}$ increase followed by Pallegoda series. Both soils showed comparatively poor pH buffering abilities (Liyanage et al., 2012). 

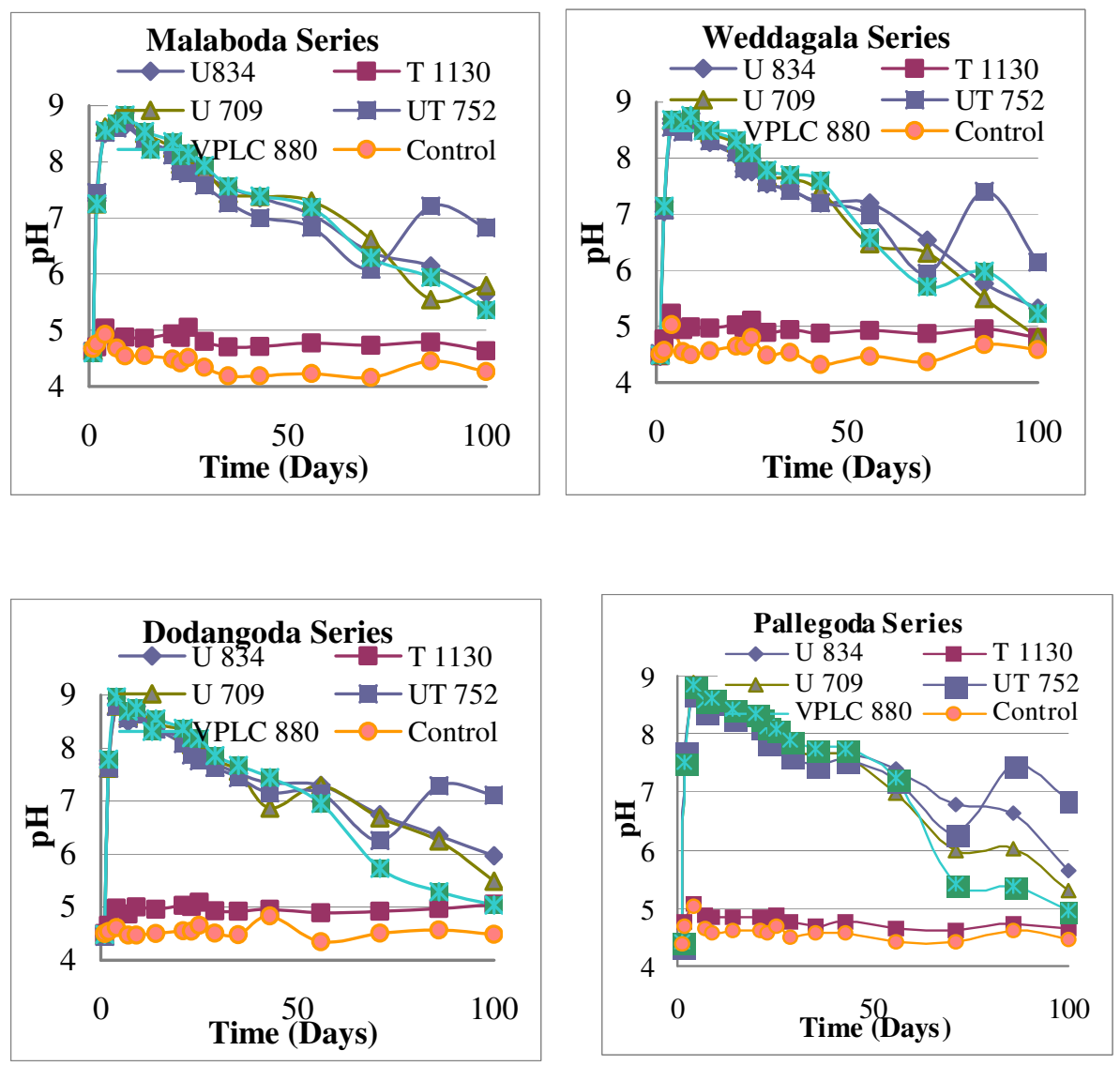

Fig. 3. Periodical changes of soil $\mathrm{pH}$ in each soil series as affected by fertilizer treatments

Among treatments, $\mathrm{pH}$ of VPLC 880 mixture treated pots reached towards its initial level while the other urea based mixtures have further recorded an elevated $\mathrm{pH}$ even after 100 days of treatment application. However, T 1130 and the control treatments were not significantly different where $\mathrm{T} 1130$ showed an elevated $\mathrm{pH}$ than the control. Transformations of Ammonium sulfate in $\mathrm{T} 1130$ may have produced strongly acidic $\mathrm{SO}_{4}{ }^{-2}$ ions and weakly basic $\mathrm{NH}_{4}{ }^{+}$ions so that a $\mathrm{pH}$ change may have been compensated. However, in the case of urea, the option was only to produce weak acids if at all.

Although VPLC 880 recorded the highest $\mathrm{pH}$ after treatments application, at the end of the experiment it reached the initial $\mathrm{pH}$ quickly than the other urea based mixtures. Further, application of Dolomite for UT 752 fertilizer treatment as recommended also recorded another peak as it increased the soil $\mathrm{pH}$ due to readily dissolving fine portion of the dolomite powder. $\mathrm{pH}$ in U709 and U 834 fertilizer treatments also showed similar levels, irrespective to kieserite component in $\mathrm{U}$ 834. It indicated that there is no effects on soil $\mathrm{pH}$ by addition of kieserite. Ponette et al. (1993) also found similar observations for acid soils under forest 
ecosystems. Dissolution of kieserite forms strong acidic $\mathrm{SO}_{4}^{-2}$ ions and strong basic $\mathrm{Mg}^{+2}$ ions thus, neutralizing each other maintaining the $\mathrm{pH}$ more or less constant.

\section{Ammonia volatilization}

Amount of ammonia volatilized was determined and quantified for the period of 100 days. As the Pre-test conducted showed that ammonia volatilization is significantly different with time, the data were analyzed individually at each sampling time as showed in the Table 3. Ammonia volatilization was greater initially in Weddagala Series and lowest in Pallegoda Series. Cumulative ammonia volatilization sequenced Dodangoda Series $>$ Weddagala Series $>$ Malaboda Series >Pallegoda Series for the period of 100 days despite Weddagala Series showed a rapid volatilization initially.

Table. 3. Level of significance for $\mathrm{NH}_{3}$ volatilization of Soil Series and treatments during 100 days

\begin{tabular}{lccc}
\hline \multicolumn{1}{c}{ Time (Days) } & Soil & Treatment & Soil * Treatment \\
\hline 1 & $* *$ & $* *$ & $* *$ \\
2 & $* *$ & $* *$ & $\mathrm{~ns}$ \\
4 & $* *$ & $* *$ & $\mathrm{~ns}$ \\
7 & $* *$ & $* *$ & $*$ \\
10 & $* *$ & $* *$ & $* *$ \\
14 & $* *$ & $* *$ & $\mathrm{~ns}$ \\
21 & $* *$ & $* *$ & $\mathrm{~ns}$ \\
25 & $* *$ & $* *$ & $\mathrm{~ns}$ \\
29 & $* *$ & $* *$ & $\mathrm{~ns}$ \\
35 & $* *$ & $* *$ & $\mathrm{~ns}$ \\
43 & $*$ & $* *$ & $\mathrm{~ns}$ \\
56 & $*$ & $* *$ & $*$ \\
71 & $*$ & $* *$ & $\mathrm{~ns}$ \\
86 & $\mathrm{~ns}$ & $* *$ & $\mathrm{~ns}$ \\
100 & $*$ & $* *$ & $*$ \\
\hline
\end{tabular}

$*=\mathrm{P} \leq 0.05, \quad * *=\mathrm{P} \leq 0.01, \quad \mathrm{~ns}=$ not significant

Dodangoda series is a gravelly soil and therefore, soil temperature may have increased during the day time than that of the other soils promoting the volatilization in this series. At the elevated temperature, retaining of $\mathrm{NH}_{4}{ }^{+}$ions in the soil solution is challenging and may try to move towards exchangeable sites. As Dodangoda Series showed a low CEC value with other factors in optimum, $\mathrm{NH}_{3}$ may be escaped more to the atmosphere as reported by Fenn and Kiessel, 1976 for such other soils. Further, $\mathrm{pH}$ of this series was also increased rapidly compared to the other soils even though not significant, indicating a lower $\mathrm{pH}$ buffering capacity. Liyanage et al. (2012) indicated that the Dodangoda Series and Pallegoda Series come under the lower $\mathrm{pH}$ buffering capacity class among all tea growing soils too. It may also have affected higher $\mathrm{NH}_{3}$ volatilization losses comparatively. Pallegoda Series showed least $\mathrm{NH}_{3}$ losses even under low $\mathrm{pH}$ buffering capacity. This may have been due to comparatively high organic carbon content of $1.87 \%$ found. This is a good indication to state that better management practices could reduce loss of $\mathrm{NH}_{3}$ even in an inherently poor soil. 
Rate of ammonia volatilization was highest at the second day after fertilizer application in all treatments except for T 1130 and control. Among treatments, VPLC 880 showed the highest volatilization rate of $0.15 \mathrm{~g} /$ day at the second day. Figure 4 illustrates the changes of $\mathrm{NH}_{3}$ volatilization with time.

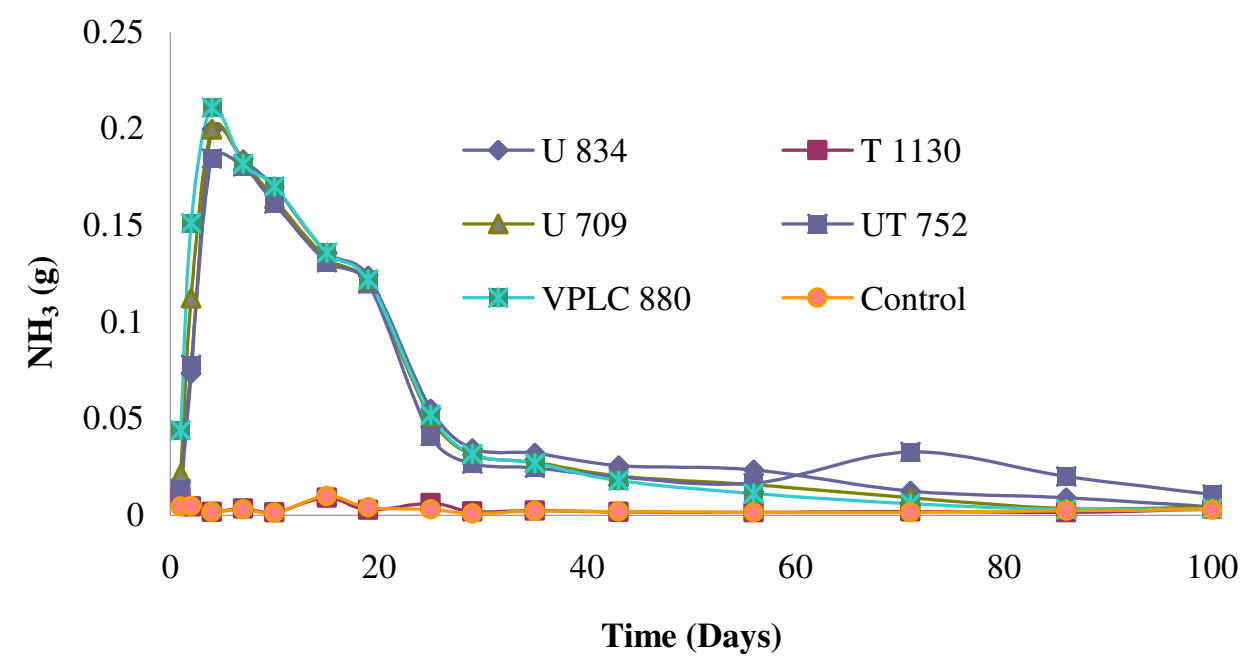

Fig. 4. Means of periodical changes of ammonia volatilization in all Soil Series

Fertilizer treatments showed significant differences in all soil series tested at $\mathrm{P}<0.01$. Among the treatments VPLC 880 showed the highest $\mathrm{NH}_{3}$ volatilization losses as illustrated in figure 5 . 

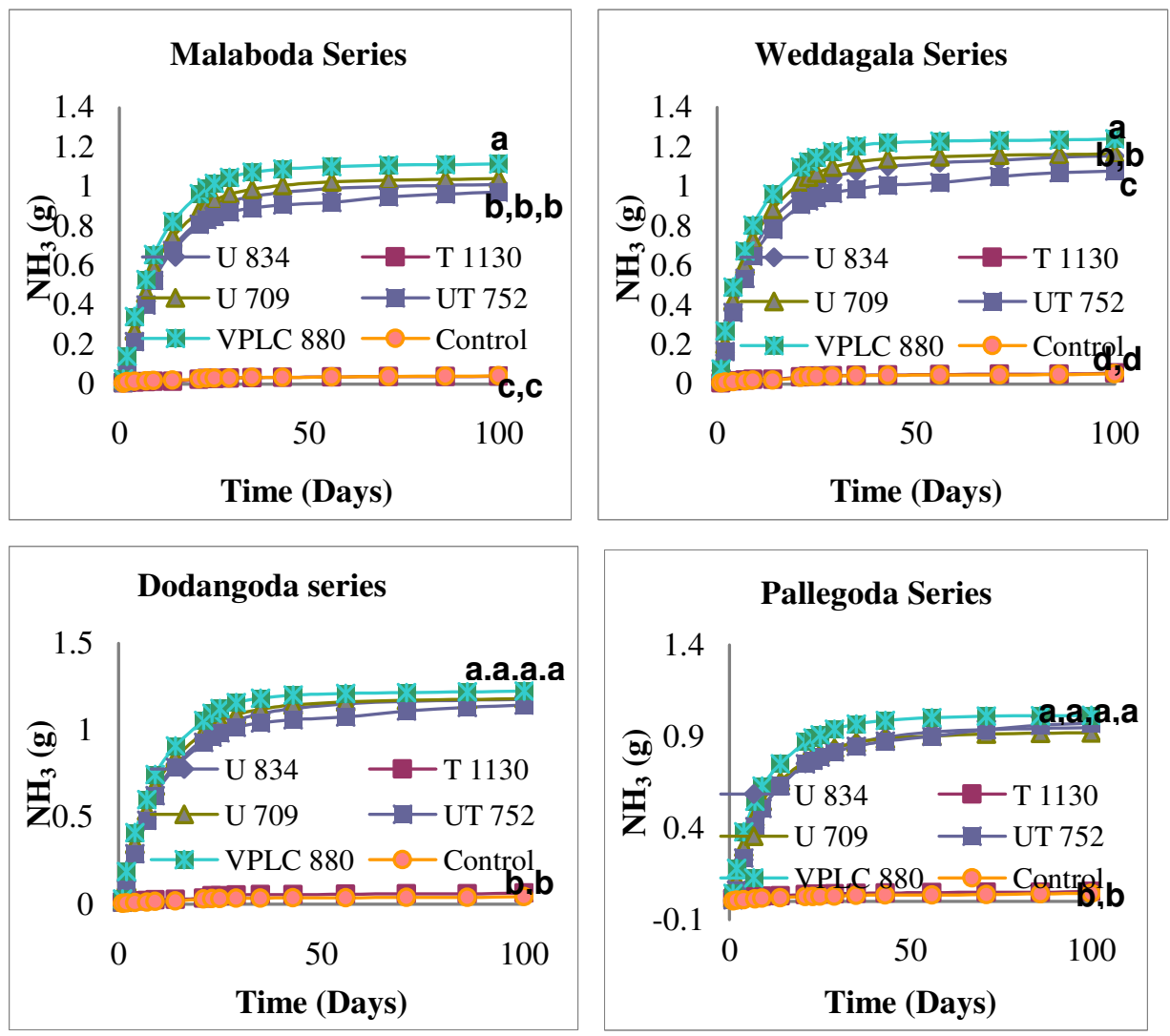

Fig. 5. Cumulative quantities of ammonia volatilized from each Soil Series with treatments (a, b, $c$ and denotes the significance level at $\mathbf{P}<0.05)$

Amount of nitrogen present in all fertilizer treatments were similar. However, $\mathrm{N}: \mathrm{P}_{2} \mathrm{O}_{5}: \mathrm{K}_{2} \mathrm{O}$ ratios in these treatments were different and VPLC 880 contained the highest $\mathrm{N} \%$ as 34.5. (U709-28.2\%, UT $752-26.6 \%$, U $834-24.0 \%$, T $1130-17.7 \%$ ). This may be a reason for higher $\mathrm{NH}_{3}$ losses among treatments. $\mathrm{U} 709$ is the second highest $\mathrm{NH}_{3}$ volatilizing treatment which had second highest $\mathrm{N} \%$. On the other hand, VPLC 880 has the lowest murriate of potash content in the mixture. Chloride ions present in $\mathrm{KCl}$ evidenced negative impact for $\mathrm{NH}_{3}$ volatilization. Witter and Kirchmann (1989) found that chloride ions binds with $\mathrm{NH}_{4}{ }^{+}$ ions and thereby reduce $\mathrm{NH}_{3}$ emission during the decomposition of poultry manure.

Application of dolomite to the fertilizer treatment UT 752 after fifty days of treatment application had a considerable influence on ammonia volatilization. It has clearly illustrated in all Soil Series as a sudden increase of $\mathrm{NH}_{3}$ loss in cumulative curves (figure 5). When $\mathrm{pH}$ increases as shown in figure 4, part of $\mathrm{NH}_{4}{ }^{+}$may have been converted to $\mathrm{NH}_{3}$ and evaporated from the soil. Particularly, all four Soil Series show comparatively lower buffering. 


\section{Nitrogen balance}

Nitrogen removal as from each soil series and in each treatment were calculated and data are illustrated in the Table 4 and percentage loss of $\mathrm{N}$ to the added fertilizer $\mathrm{N}$ are shown in Table 5.

Table 4. Amount of ammonia volatilized (g) in each treatment of tested soils

\begin{tabular}{lcccccc}
\hline \multicolumn{7}{c}{ Soil Series } \\
\hline Treatment & Malaboda & Weddagala & Dodangoda & Pallegoda & Mean & LSD \\
\hline U 834 & 1.0104 & 1.1538 & 1.1780 & 0.9482 & 1.0726 & \\
T 1130 & 0.0412 & 0.0556 & 0.0639 & 0.5341 & 0.0535 & \\
U 709 & 1.0410 & 1.1658 & 1.1830 & 0.9210 & 1.0777 & \\
UT 752 & 0.9727 & 1.0791 & 1.1463 & 0.9726 & 1.0427 & 0.0602 \\
VPLC 880 & 1.1163 & 1.2402 & 1.2254 & 1.0155 & 1.1494 & \\
Control & 0.0427 & 0.0516 & 0.0435 & 0.0437 & 0.0453 & \\
Mean & 0.7041 & 0.7910 & 0.8067 & 0.6590 & & \\
LSD & & & 0.0491 & & & \\
\hline \multicolumn{7}{c}{ CV\% } \\
\hline
\end{tabular}

Total $\mathrm{N}$ quantity added as fertilizer was $4 \mathrm{~g}$ in each fertilizer treatment. After 100 days of experimental period, all urea based fertilizer mixtures lost more than $1 \mathrm{~g}$ of $\mathrm{N}$ in form of $\mathrm{NH}_{3}$ gas. VPLC 880 fertilizer lost the highest $\mathrm{N}$ amount of $1.15 \mathrm{~g}$ which represents $29 \%$ of the total $\mathrm{N}$ added. In contrast, $\mathrm{T} 1130$ fertilizer showed a negligible amount of $\mathrm{N}$ loss over $\mathrm{NH}_{3}$ which was almost similar to the non-treated treatment where no fertilization was done. However, in a comparable study Duminda (2000) found that the $\mathrm{NH}_{3}$ losses in Red Yellow Podzolic soils treated with $400 \mathrm{~kg} \mathrm{~N} /$ ha urea as $16 \%$.

Table 5. Mean percentages of ammonia volatilized to total applied in each treatment in all soils after 100 days of treatment application

\begin{tabular}{lr}
\hline \multicolumn{1}{r}{ Treatment } & $\mathbf{N H}_{\mathbf{3}} \mathbf{\%}$ \\
\hline U 834 & 26.82 \\
T 1130 & 1.34 \\
U 709 & 26.94 \\
UT752 & 26.07 \\
VPLC 880 & 28.74 \\
\hline
\end{tabular}

$\mathrm{NH}_{3}$ losses in this study complies with the findings of Bavanandan and Fernando (1970). Bavanandan and Fernando (1970) estimated the losses of $\mathrm{NH}_{3}$ from urea, Sulphate of ammonia and calcium ammonium nitrate broadcast on St. Coombs estate soils (elevation $1500 \mathrm{~m}$, temperature $18-26^{\circ} \mathrm{C}$ ) as $24-33 \%, 0.2-4.7 \%$ and $0.4-1.8 \%$ respectively. However, few limitations were encountered in this study despite all possible precautions taken. Temperature inside the glasshouse was elevated particularly in the hot days even more than the atmospheric temperature recorded in low-country region. It may have contributed little to higher $\mathrm{NH}_{3}$ losses at times. Moisture content was maintained at the $60 \%$ of the field capacity of these soils which may have not been the actual conditions at the tea field. Continuous removal of $\mathrm{NH}_{3}$ by acid traps may have favoured the rate of conversion of $\mathrm{NH}_{4}{ }^{+}$to $\mathrm{NH}_{3}$, 
which may not occur at the field apart from windy areas. Further, soil surface in the field is covered with litter or short height grasses and forages which also help to reduce $\mathrm{NH}_{3}$ loss.

\section{CONCLUSIONS}

Ammonia volatilization is one of the major nitrogen losses in the low-country tea growing soils of the country. It contributes to around $26 \%$ of $\mathrm{N}$ losses of the added fertilizers. All tested Soil Series have shown similar behaviour in soil $\mathrm{pH}$ changes with the application of urea based fertilizer mixtures which had greater influences on $\mathrm{NH}_{3}$ volatilization. Owing to poor physical and chemical properties in Dodangoda soil series, it showed the highest $\mathrm{NH}_{3}$ losses among tested Soil Series. $\mathrm{NH}_{3}$ losses sequenced as Dodangoda > Weddagala > Malaboda $>$ Pallegoda soil Series.

VPLC 880 treatment, which is the currently recommended fertilizer mixture for mature tea in low country recorded the highest $\mathrm{NH}_{3}$ losses reaching $29 \%$ of added nitrogen. Hence, this could be considered as one of the major reasons for the claim of tea smallholders on poor responses to tea the fertilizer mixtures particularly in the low country tea growing region. In contrast, T 1130 which is ammonium sulfate based fertilizer showed negligible $\mathrm{N}$ losses even under poor soil conditions.

Findings of this study should be taken into consideration for future fertilizer recommendations particularly in low-country tea growing regions as these losses are substantial. Split applications could reduce $\mathrm{NH}_{3}$ losses as it addresses lower $\mathrm{pH}$ buffered soils despite the cost incurred than use of sulphate of ammonia based mixtures having other detrimental effects. However, a field level descriptive research is needed to confirm these findings.

\section{REFERENCES}

Adriano, D.C., Pratt, P.F. and Bishop, S.E. (1971). Fate of inorganic forms of N and salt from land-disposed manure from dairies. pp. 243-246 In: Livestock waste management and pollution abatement. Livestock Waste Proc. (Columbus. Ohio) ASAE Publ. PROC-271, St. Joseph, Mich.

Anon, (2010). T.R.I. Advisory circular No. SP 10. Interim circular on Fertilizer recommendation for mature tea in small holdings serial no. 01/10. Tea Research Institute of Sri Lanka. St Coombs Estate, Talawakelle. Sri Lanka.

Anon, $\left(2000^{\mathrm{a}}\right)$. T.R.I. Advisory circular No. SP 3. Fertilizer recommendations for mature tea serial no. 00/3. Tea Research Institute of Sri Lanka. St Coombs Estate, Talawakelle. Sri Lanka.

Anon, $\left(2000^{b}\right)$. SAS for Windows 9.1. SAS Institute Inc. Cary, NC. 27513, USA.

Bavananthan, V. P. and Fernando V. (1970). Studies on the use of urea as a fertilizer for tea in Ceylon 2 - Urease activity in tea Soils. Tea Quart. 41, 94 - 98. 
Byrnes, B.H. (2000). Liquid fertilizers and nitrogen solutions. In: International Fertilizer Development Center. Fertilizer manual. Alabama, Kluwer Academic publishers, the Netherland. 20-44.

Duminda, D.M.S. (2000). The fate of applied nitrogen fertilizer in an acid tea soil. Undergraduate project report. Faculty of Agriculture, University of Ruhuna, Mapalana, Kamburupitiya, Sri Lanka. 61-63.

Fenn, L.B., and Kissel D.E. (1973). Ammonia volatilization from surface applications of ammonium compounds on calcareous soils, I. General theory. Soil Sci. Soc. of Am. Proc, 37, 855-859.

Fenn, L.B., and Kissel, D.E. (1974). Ammonia volatilization from surface applications of ammonium compounds on calcareous soils. II. Effects of temperature and rate of ammonium nitrogen application. Soil Sci. Soc. of Am. Proc. 38, 206 - 210.

Fenn, L.B., and Kissel D.E. (1976). The influence of cation exchange capacity and depth of incorporation on ammonia volatilization from ammonium compounds applied to calcareous soils. Soil Sci. Soc. Am. J. 40, 394 - 398.

Ferguson, R.B., Kissel D.E., Koelliker J.K. and Basel, W. (1984). Ammonia volatilization from surface-applied urea: effect of hydrogen ion buffering capacity. Soil Sci. Soc. Am. J. $48,578-582$.

Freney, J.R., Leuning, R., Simpson, J.R., Denmead, O.T. and Muirhead, W.A. (1985). Estimating ammonia volatilization from flooded rice fields by simplified methods. Soil Sci. Soc. Am. J. 49, 1049-1054.

Gordon, R., Leclerc, M., Schuepp, P. and Brunker, R. (1988). Field estimates of ammonia volatilization from swine manure by a simple micrometeorological technique. Can. J. Soil Sci. 68,369 - 380 .

Hargrove, W.L. (1988). Soil, environmental and management factors influencing ammonia volatilization under field conditions. pp.17-36. In: Bock, B.R. \& Kissel, D.E. (ed.) Ammonia volatilization from urea fertilizers. Alabama, NFDC, TVA.

Hoff, J.D., Nelson, D.W. and Sutton, A.L. (1981). Ammonia volatilization from liquid swine manure applied to cropland. J. Environ. Qual. 10, 90 - 95.

Liyanage, L.R.M.C., Jayakody, A.N., Wijayatunga, W.M.S. and Gunaratne, G.P. (2012). Feasibility of using soil $\mathrm{pH}$ buffering capacity for dolomite recommendation for tea growing soils in Sri Lanka. S.L.J.Tea Sci. 77(1/2), 57 - 69

Ping, J., Bremer, E. and Janzen, H.H. (2000). Foliar uptake of volatilized ammonia from surface-applied urea by spring wheat. Com. Soil Sci. Plant Anal. 31, 165 - 172. 
Ponette, Q., Dufey J.E., Weissen, F. and van Praag H.J. (1993). Downward effects of dolomite and kieserite on two acid soils differing in their organic carbon content. Com. Soil Sci. Plant Anal. 24(13-14), 1439 - 1452.

Prasertsak, P., Freney, J.R., Saffiga, P.G., Denmead, O.T. and Prove, B.G. (2001). Fate of urea nitrogen applied to a banana crop in the wet tropics of Queensland. Nutrient Cycling in Agro ecosystems. 59, 65 - 73.

Salter, R.M. and Schollenberger, C.J. (1938). Farm manure. pp. 445-461 In: Soils and men, 1938 Yearbook of Agriculture. U.S. Government Printing Office, Washington, D.C.

Tennakoon, P.L.K., Hettiarachchi, L.S.K., Zoysa, A.K.N. and Gunaratne, G.P. (2003). Transformations of applied urea in soils of tea growing areas as affected by a urease inhibitor (Agrotain). S.L.J. Tea Sci. 68(1), 20 - 33.

Sivasubramanium S. (1980). The use of fertilizers for tea in Sri Lanka. Tea Quart. 49, 137 142.

Wickramasinghe, K.N. (1986). The current thinking on the substitution of urea for Sulphate of ammonia in tea plantations. Tea Bulletin 6, 20 - 35 .

Wickramasinghe, K.N., Nalliah, P. and Wijedasa, M.A. (1985). Effect of urea and ammonium sulphate on the nitrification and the release of potassium, magnesium and calcium in acid tea soils, S.L.J. Tea Sci. 54-1, 11.

Witter, E. and Kirchmann, H. (1989). Effects of addition of calcium and magnesium salts on ammonia volatilization during manure decomposition. Plant and soil 115(1), 53 - 58. 